\title{
Hubungan Jumlah Leukosit Pre Operasi dengan Kejadian Komplikasi Pasca Operasi Apendektomi pada Pasien Apendisitis Perforasi di RSUP Dr. M. Djamil Padang
}

\author{
Annisa Amalina ${ }^{1}$, Avit Suchitra ${ }^{2}$, Deddy Saputra ${ }^{2}$
}

\section{Abstrak}

Keterlambatan tindakan pada apendisitis akut akan menimbulkan penyulit berupa perforasi yang berakibat peningkatan morbiditas dan mortalitas. Perforasi appendiks berhubungan dengan peningkatan jumlah leukosit darah (leukositosis) dan dapat meningkatkan resiko terjadinya komplikasi pasca apendektomi. Tujuan penelitian ini adalah menentukan hubungan jumlah leukosit pre-operasi terhadap kejadian komplikasi pasca operasi apendektomi pada pasien apendisitis perforasi di RSUP Dr. M. Djamil Padang periode tahun 2015 sampai 2016. Penelitian ini merupakan studi analitik dengan pendekatan cross sectional. Jumlah sampel sebanyak 52 rekam medik pasien yang telah menjalani apendektomi yang sebelumnya diperiksa jumlah leukosit preoperasi. Data dianalisis secara univariat dan bivariat menggunakan uji korelasi Spearman. Hasil analisis univariat didapatkan rerata jumlah leukosit yaitu 18.966 sel $/ \mu$ l dengan sampel yang mengalami komplikasi pasca operasi yaitu 24 orang $(46,2 \%)$ sedangkan yang tidak mengalami komplikasi yaitu 28 orang yaitu $(53,8 \%)$. Sampel yang mengalami komplikasi pasca operasi dengan leukositosis yaitu 22 orang $(66,66 \%)$ sedangkan yang mengalami komplikasi pasca operasi tanpa disertai leukositosis yaitu 11 orang (33,34\%). Sampel dengan jumlah leukosit normal disertai dengan komplikasi pasca operasi yaitu 2 orang $(10,52 \%)$ sedangkan sampel dengan jumlah leukosit normal tapi tidak mengalami komplikasi pasca operasi yaitu 17 orang $(89,48 \%)$. Hasil analisis bivariat didapatkan $p=0.000 \quad(p<0.05)$ dengan derajat kekuatan hubungan sedang $r=0,537$. Simpulan studi ini ialah terdapat hubungan yang bermakna antara jumlah leukosit pre operasi dengan kejadian komplikasi pasca operasi apendektomi pada pasien apendisitis perforasi di RSUP Dr M. Djamil Padang.

Kata kunci: apendisitis, leukosit, perforasi, komplikasi

\section{Abstract}

Every delayed action will cause perforation as complication, which will increase the morbidity and mortality rate. Perforation of the appendix is associated with increasing number of leukocytes and may increase the risk of complications after appendectomy. The objective of this study was to determine the relation between the number of preoperative leukocytes and the incidence of postoperative apendectomy complications in patients with perforated appendicitis in Dr. M. Djamil Padang hospital in the period of 2015-2016. This was an analytic research with cross sectional approach. There were 52 medical records of patients who have undergone appendectomy and performed preoperative leukocytes counting. Data were analyzed by univariate and bivariate statistical with Spearman correlation test. The result of univariate analysis showed that the average number of leukocytes in perforated appendicitis patients was $18,966 \mathrm{cell} / \mu \mathrm{l}$. The amount of samples with postoperative complication were 24 people (46,2\%), while those without postoperative complication were 28 people (53,8\%). The patients with postoperative complication and increasing leukocytes (leukocytosis) were 22 people (66,66\%) while those who had postoperative complication without leukocytosis were 11 people (33,34\%). The samples with normal leukocyte counts and accompanied by postoperative complications were 2 people (10.52\%) while samples with normal leukocyte counts but no postoperative complications were 17 people (89.48\%). The result obtained from bivariate analysis was $p=0.000(p<0.05)$ with medium strength relation, $r=0,537$. The conclusion is a significant relation between preoperative leukocyte count and incidence of postoperative apendectomy complication in perforation appendicitis patients at Dr M. Djamil Padang hospital.

Keywords : apendicitis, leukocyte, perforated, complications 
Affiliasi penulis 1. Prodi Kedokteran Fakultas Kedokteran Universitas Andalas Padang, 2. Bagian Bedah FK Unand/RSUP Dr. M. Djamil Padang.

Korespondensi: Annisa Amalina

Email: amalinaannisa21@gmail.com Telp: 087792631926.

\section{PENDAHULUAN}

Apendisitis merupakan peradangan akut pada apendiks vermiformis. Apendiks vermiformis memiliki panjang yang bervariasi dari 7 sampai $15 \mathrm{~cm}^{1,2}$ Apendisitis merupakan salah satu kasus tersering dalam bidang bedah abdomen yang menyebabkan nyeri abdomen akut dan memerlukan tindakan bedah segera untuk mencegah komplikasi yang umumnya berbahaya. ${ }^{2,3,4}$

Insidensi apendisitis di Asia pada tahun 2004 menurut World Health Organization (WHO) adalah $4,8 \%$ penduduk dari total populasi. ${ }^{5}$ Hasil survey angka insidensi apendisitis yaitu terdapat 11 kasus pada setiap 1000 orang di Amerika pada usia tersering 10 30 tahun dengan perbandingan laki-laki dan perempuan $1,4: 1{ }^{6}$ Menurut Departemen Kesehatan RI pada tahun 2006, angka kejadian apendisitis di Indonesia menempati urutan tertinggi di antar kasus kegawat daruratan abdomen dan menduduki urutan keempat dari seluruh penyakit abdomen terbanyak setelah dispepsia, gastritis dan duodenitis dengan jumlah pasien rawat inap sebanyak $28.040 .^{7}$

Angka kejadian apendisitis akut di Indonesia diperkirakan berkisar 24,9 kasus per 10.000 populasi. ${ }^{8}$ Apendisitis sering terjadi pada laki-laki dengan rentang usia 10-19 tahun di Ontario. ${ }^{9}$ Dalam periode 2 tahun (1 Januari 2015 s/d 31 Desember 2016) di Sumatera Barat, khususnya menurut data rekam medis pasien RSUP Dr. M Djamil Padang terdapat 199 kasus apendisitis. $^{10}$

Perjalanan dari mulai timbulnya gejala menuju perforasi terjadi begitu cepat, sebanyak $20 \%$ kasus perforasi apendiks terjadi 48 jam, bahkan dapat 36 jam setelah timbulnya gejala. Hal ini menunjukkan bahwa timbulnya perforasi sangat cepat sehingga perlu mendapatkan perhatian yang lebih serta penanganan yang tepat dari para dokter. ${ }^{4,11}$

Diagnosis apendisitis diawali dengan melakukan anamnesis dan pemeriksaan fisik. ${ }^{6}$ Dalam mendiagnosis apendisitis, anamnesis dan pemeriksaan memegang peranan utama dengan akurasi $76-80 \%$ dengan tingkat kesulitan anak-anak yang lebih tinggi dari pada dewasa karena diduga faktor mereka yang tidak bisa menceritakan sendiri terkait riwayat penyakit. $^{12}$

Penegakkan diagnosis pada pasien apendisitis dengan gejala klasik sekalipun sangat rumit, karena banyak faktor yang menyebabkan variasi dari gambaran klinis "klasik" seperti lokasi apendiks abnormal, umur lanjut, obesitas dan kehamilan. Oleh karena itu, dokter perlu melakukan pemeriksaan penunjang. Nilai jumlah leukosit, presentase neutrofil, dan $C$-reactive protein (CRP) dapat digunakan sebagai informasi yang bermanfaat dalam mendiagnosis apendisitis dan komplikasinya. Dapat juga dilakukan Ultrasonography (USG) dan Computed Tomography (CT) scan untuk membantu mencari differential diagnosis atau untuk membantu pemeriksaan pasien yang hasil diagnosisnya masih diragukan. ${ }^{13}$

Penurunan angka morbiditas dan mortalitas dicapai dengan adanya penatalaksanaan operatif dalam menangani kasus apendisitis. ${ }^{14}$ Tindakan bedah yang paling tepat dan baik adalah apendektomi. ${ }^{15}$ Terjadinya perforasi apendiks sering dihubungkan dengan tingginya leukosit darah saat diagnosis ditegakkan, lamanya penanganan sejak gejala muncul, dan gejala demam tinggi lebih dari $38,5{ }^{\circ} \mathrm{C}$ sebagai bentuk respon inflamasi tubuh. ${ }^{16}$

Apendik perforasi selalu diawali oleh obstruksi lumen apendik oleh berbagai sebab. Hal ini menyebabkan terjadinya peningkatan intra luminal yang mengakibatkan gangguan vaskularisasi hingga terjadi apendisitis perforasi. Terjadinya perforasi apendiks, angka kejadian komplikasi menjadi lebih besar. Untuk kasus apendisitis tanpa perforasi, angka kejadian infeksi paska bedah kurang dari 5\%. Sementara dengan terjadinya perforasi, angka kejadiannya dapat meningkat menjadi 20\%. ${ }^{7}$ Keterlambatan diagnosis juga dapat meningkatkan angka mortalitas dan morbiditas. Ada sekitar 11,2\%-30\% keterlambatan diagnosis ini berakibat perforasi intestinal. ${ }^{16,17}$

Pemeriksaan penunjang berupa jumlah leukosit menunjukkan sembilan puluh persen pasien apendisitis akut menunjukkan peningkatan hitung jumlah leukosit antara $10.000 \mathrm{sel} / \mu \mathrm{l}$ sampai dengan $15.000 \mathrm{sel} / \mu \mathrm{l} .^{14}$ Leukosit melebihi 18.000-20.000 sel/ $\mu \mathrm{l}$ menandakan kemungkinan telah terjadi perforasi apendiks. ${ }^{13,14}$ 
Apendisitis perforasi dapat meningkatkan risiko terjadinya komplikasi paska apendektomi, meskipun secara umum apendektomi merupakan tindakan bedah yang relatif tidak membahayakan jiwa dengan angka kematian paska bedah untuk apendiks perforasi yaitu 5,1 per 1000 kasus. $^{7}$ Komplikasi yang sering terjadi setelah dilakukan apendektomi yaitu infeksi paska bedah, abses intraabdomen, peritonitis umum, dan komplikasi pascaoperasi seperti fistula dan infeksi luka operasi. $^{14,16}$

\section{METODE}

Jenis penelitian ini adalah studi analitik dengan pendekatan cross sectional. Penelitian ini dilaksanakan selama 2 bulan. Populasi penelitian ini adalah seluruh data rekam medik pasien apendisitis perforasi di bagian rekam medik RSUP Dr. M. Djamil Padang antara 1 Januari 2015 - 31 Desember 2016. Sampel penelitian ini adalah semua populasi yang telah memenuhi kriteria Inklusi dan ekslusi. Kriteria inklusi adalah pasien apendisitis perforasi yang menjalani operasi dan dirawat di RSUP Dr. M. Djamil Padang periode tahun 2015 sampai dengan 2016, berusia $\geq 12$ tahun dan dioperasi dengan laparotomy. Kriteria ekslusi adalah data rekam medis tidak lengkap, berkas rekam medis pasien memuat variabel yang dibutuhkan tapi tidak dapat dibaca dan pasien dengan penyakit TBC, diabetes mellitus, immunocompromised, serta penyakit infeksi lain yang diderita pasien.

Analisis univariat dilakukan terhadap tiap variabel dari hasil penelitian. Tujuan dari analisis ini untuk menghasilkan distribusi dan persentase dari tiap variabel. Analisis bivariat dimaksudkan untuk melihat hubungan kedua variabel, yaitu variabel bebas dan terikat menggunakan uji statistik korelasi Spearman untuk varibel dependen nominal dengan derajat kemaknaan $p<0,05$ sebagai uji hipotesis dan dengan interpretasi kekuatan korelasi (r). Besar sampel pada penelitian ini setelah menggunakan rumus Lemeshow adalah sebanyak 52 orang.
HASIL

Tabel 1. Distribusi usia penderita apendisitis perforasi

\begin{tabular}{ccc}
\hline Usia & Frekuensi & $\%$ \\
\hline $12-24$ & 29 & 55,8 \\
$25-44$ & 17 & 32,7 \\
$45-64$ & 5 & 9,6 \\
$>65$ & 1 & 1,9 \\
\hline Total & 52 & $100 \%$ \\
\hline
\end{tabular}

Berdasarkan Tabel 1 diperoleh data bahwa usia penderita apendisitis peforasi terbanyak pada usia 12 24 tahun yaitu sebanyak 29 orang $(55,8 \%)$, usia $25-44$ tahun yaitu sebanyak 17 orang $(32,7 \%)$, sedangkan untuk usia 45-64 tahun sebanyak 5 orang $(9,6 \%)$ dan untuk usia diatas 65 tahun hanya 1 orang $(1,9 \%)$.

Tabel 2. Distribusi jenis kelamin penderita apendisitis perforasi

\begin{tabular}{lcc}
\hline Jenis Kelamin & Frekuensi & $\%$ \\
\hline Laki-laki & 29 & 55,8 \\
Perempuan & 23 & 44,2 \\
\hline Total & 52 & $100 \%$ \\
\hline
\end{tabular}

Berdasarkan Tabel 2 diperoleh data bahwa dari 52 kasus apendisitis perforasi sebagian besar berjenis kelamin laki-laki yaitu sebanyak 29 orang (55,8\%), sisanya 23 orang $(44,2 \%)$ berjenis kelamin perempuan.

Tabel 3. Distribusi komplikasi pasca operasi penderita apendisitis perforasi

\begin{tabular}{ccc}
\hline $\begin{array}{c}\text { Komplikasi } \\
\text { Pasca Operasi }\end{array}$ & Frekuensi & $\%$ \\
\hline Ada Komplikasi & 24 & 46,2 \\
Tidak Ada & 28 & 53,8 \\
Komplikasi & \\
Total & 52 & $100 \%$ \\
\hline
\end{tabular}


Berdasarkan Tabel 3 diperoleh data bahwa terdapat hampir setengah kasus apendisitis perforasi mengalami komplikasi pasca operasi yaitu sebanyak 24 orang $(46,2 \%)$, dan sebanyak 28 orang $(53,8 \%)$ tidak mengalami komplikasi pasca operasi.

Tabel 4. Distribusi jenis komplikasi pasca operasi penderita apendisitis perforasi

\begin{tabular}{lcc}
\hline Jenis Komplikasi & Frekuensi & $\%$ \\
\hline lleus Obstruksi & 1 & 1,9 \\
Infeksi Luka Op & 17 & 32,7 \\
Kematian & 3 & 5,8 \\
Reperforasi & 1 & 1,9 \\
Sepsis & 2 & 3,8 \\
Tidak Ada & 28 & 53,8 \\
\hline \multicolumn{1}{c}{ Total } & 52 & $100 \%$ \\
\hline
\end{tabular}

Berdasarkan Tabel 4 diperoleh data bahwa komplikasi pasca operasi terbanyak yaitu infeksi luka operasi yaitu sebanyak 17 orang $(32,7 \%)$, ileus obstruksi terdapat 1 orang $(1,9 \%)$, kematian sebanyak 3 orang (5,8\%), reperforasi yaitu sebanyak 1 orang $(1,9 \%)$, dan sepsis berjumlah 2 orang $(3,8 \%)$.

Tabel 5. Distribusi jumlah leukosit penderita apendisitis perforasi

\begin{tabular}{lcll}
\hline Variabel & $\begin{array}{c}\text { Rerata } \pm \text { SD } \\
(\mathrm{sel} / \mu \mathrm{l})\end{array}$ & $\begin{array}{c}\text { Min } \\
(\mathrm{sel} / \mu \mathrm{l})\end{array}$ & $\begin{array}{c}\text { Maks } \\
(\mathrm{sel} / \mu \mathrm{l})\end{array}$ \\
\hline Leukosit & $18966,64 \pm 8254,83$ & 6800 & 43600 \\
\hline
\end{tabular}

Pengelolaan terhadap 52 sampel, diperoleh hasil nilai terendah jumlah leukosit pada seluruh sampel pasien apendisitis perforasi yaitu $6800 \mathrm{sel} / \mu \mathrm{l}$ dan nilai tertinggi adalah $43600 \mathrm{sel} / \mu \mathrm{l}$. Rerata jumlah leukosit pada sampel sebesar 18966,64 sel/ $\mu$ l dengan nilai standar deviasi (SD) sebesar $8254,83 \mathrm{sel} / \mu \mathrm{l}$.

Pada penelitian ini didapatkan pada pasien apendisitis perforasi dengan leukosit $>15.000$ frekuensi paling banyak terjadinya komplikasi pasca operasi yaitu sebanyak 22 orang $(66,66 \%)$ sementara kejadian tidak adanya komplikasi pasca operasi paling banyak pada pasien apendisitis perforasi dengan leukosit 500015.000 yaitu 17 orang $(89,48 \%)$.

Hasil uji korelasi, didapatkan nilai significancy 0,000 yang menunjukkan bahwa korelasi antara jumlah leukosit pre operasi dengan kejadian komplikasi pasca operasi apendektomi pada pasien apendisitis perforasi di RSUP Dr. M. Djamil Padang periode 2015 sampai 2016 adalah bermakna. Nilai korelasi Spearman sebesar 0,537 menunjukkan bahwa arah korelasi positif dengan kekuatan korelasi sedang.

\section{PEMBAHASAN}

Distribusi rerata jumlah leukosit pada pasien apendisitis perforasi didapatkan 18.966,64 sel/ $\mu$ l. Angka ini lebih tinggi daripada penelitian yang dilakukan oleh Asrahadi pada tahun 2017 yang menyatakan nilai ratarata leukosit terhadap kejadian apendisitis perforasi yaitu $16.644 \mathrm{sel} / \mu \mathrm{l} .{ }^{18} \mathrm{Hal}$ ini dikarenakan sampel yang diambil berasal dari 3 rumah sakit yang berbeda di Kota Padang dengan jumlah sampel yang lebih sedikit. Hasil ini sejalan dengan penelitian Marisa et al di RSUD Tugurejo Semarang yang mendapatkan rerata jumlah leukosit sebesar 18.209,43 sel/ $/$ l. Studi ini memiliki kesamaan desain penelitian yaitu desain cross sectional dengan menggunakan data rekam medik lengkap dengan hasil laboratorium. ${ }^{19}$

Perbedaan hasil ini menunjukkan bahwa relatif perbedaan peningkatan jumlah leukosit ini bisa disebabkan oleh perbedaan subjek, metode penelitian, maupun metode hematologi analyzer yang digunakan apakah penelitian prospektif dengan laporan patologi anatomi atau penggunaan data rekam medik lengkap dengan hasil laboratorium. Penelitian Sengupta et al pada tahun 2009 mendapatkan rerata jumlah leukosit lebih rendah pada pasien apendisitis perforasi yaitu $15.500 \mathrm{sel} / \mu \mathrm{l}$ di Edinburg UK dengan metode penelitian prospektif dan penggunaan laporan patologi anatomi. ${ }^{20}$

Pada penelitian ini terlihat dari 52 sampel terdapat 33 orang $(63,46 \%)$ dengan jumlah leukosit pre operasi $>15.000 \mathrm{sel} / \mu \mathrm{l}$ sementara 19 orang $(36,54 \%)$ dengan jumlah leukosit pre operasi $5000-15.000 \mathrm{sel} / \mu \mathrm{l}$. Sehingga pada data hasil penelitian ini terlihat bahwa jumlah leukosit pre operasi pada pasien apendisitis perforasi juga ada yang didapatkan dalam rentang jumlah leukosit normal yaitu berkisar dari 5000-11.000 $\mathrm{sel} / \mu \mathrm{l}$ maupun dari $11.000-15.000 \mathrm{sel} / \mu \mathrm{l}$ yang menurut literatur merupakan angka jumlah leukosit pre operasi pada apendisitis akut, tapi $63,46 \%$ mempunyai leukosit $>15.000 \mathrm{sel} / \mu \mathrm{l}$ yang berarti tingginya kadar leukosit sebagai salah satu indikasi adanya perforasi appendix. 
Hasil penelitian ini sejalan dengan literatur yang menyatakan jumlah leukosit $>18.000 \mathrm{sel} / \mu \mathrm{l}$ merupakan indikasi dari terjadinya suatu apendisitis perforasi dengan atau tanpa komplikasi. ${ }^{12}$ Pada literature lain, Gearhart et al pada tahun 2008 menyatakan bahwa penemuan angka leukosit lebih dari $20.000 \mathrm{sel} / \mu \mathrm{l}$ dapat dikatakan sebagai penderita apendisitis perforasi. ${ }^{21}$

Pada penelitian ini didapatkan bahwa hampir setengah kasus apendisitis perforasi mengalami komplikasi pasca operasi yaitu sebanyak 24 orang $(46,2 \%)$ dari jumlah sampel 52 orang. Hasil ini hampir sama dengan penelitian yang dilakukan oleh Puspasari di RSUD Undata Palu yang mendapatkan hasil kasus komplikasi pada apendisitis perforasi sebanyak 35 orang $(51,5 \%)$. Perbedaan ini dikarenakan jumlah sampel penelitian yang digunakan lebih banyak yaitu 68 orang dengan desain penelitian cross sectional menggunakan metode penelitian yang sama denan peneliti yaitu rekam medis. ${ }^{22}$

Hasil yang sama juga diperoleh dari penelitian Sirikurnpiboon et al pada tahun 2015 di Thailand juga menunjukkan kesamaan hasil dengan peneliti, dimana terdapat 34 orang (33\%) yang mengalami komplikasi dari 103 sampel pasien apendisitis perforasi. Pada penelitian ini menggunakan sampel yang lebih banyak yang berasal dari rekam medis 5 tahun periode dengan jumlah sampel 206 orang. ${ }^{23}$ Omari et al pada tahun 2014 di Jordan dari 87 sampel pasien apendisitis perforasi terdapat 44 orang $(21 \%)$ yang mengalami komplikasi pasca operasi. ${ }^{24}$

Rincian jenis komplikasi pasca operasi terbanyak yaitu infeksi luka operasi yaitu sebanyak 17 orang $(32,7 \%)$, ileus obstruksi terdapat 1 orang $(1,9 \%)$, kematian sebanyak 3 orang (5,8\%), reperforasi yaitu sebanyak 1 orang (1,9\%), dan sepsis berjumlah 2 orang $(3,8 \%)$. Hal ini tidak berbeda dengan penelitian yang menyebutkan komplikasi terbanyak yang terjadi adalah infeksi luka operasi berjumlah 19 orang (18,4\%) dan reperforasi sebanyak 2 orang $(1,9 \%){ }^{23}$

Penelitian ini juga sejalan sesuai dengan literatur yang menyatakan bahwa terdapat 5 sampai 20 persen komplikasi pasca operasi dapat terjadi sebagai infeksi luka operasi. ${ }^{7}$ Kematian insidensinya mencapai 20 $35 \%$, reperforasi sebesar $1-3 \%$ dan sepsis mencapai 2,3 - 10\% sebagai komplikasi pasca operasi pada apendisitis perforasi. ${ }^{16,25}$
Hasil analisis statistik mendapatkan nilai $p$ sebesar 0,000 $(p<0,05)$ dengan uji korelasi Spearman, yang sebelumnya telah dilakukan uji normalitas dengan Kolmogorov-Smirnov, didapat nilai p sebesar 0,200 dan $0,175$ ( $p>0,05)$. Hal ini menunjukan bahwa hipotesis penelitian mengenai adanya hubungan jumlah leukosit pre operasi dengan kejadian komplikasi pasca operasi apendektomi pada pasien apendisitis perforasi dapat diterima. Hasil ini disimpulkan karena nilai maksimal $p$ untuk penerimaan hipotesis penelitian adalah 0.05 dengan derajat kesalahan $0.5 \%$.

Kekuatan hubungan yang juga dilakukan dengan uji korelasi Spearman didapatkan nilai p sebesar 0,000 $(p<0,05)$ yang menunjukkan bahwa korelasi antara jumlah leukosit pre operasi dengan kejadian komplikasi pasca operasi apendektomi pada pasien apendisitis perforasi di RSUP Dr. M. Djamil Padang periode tahun 2015 - 2016 adalah bermakna. Nilai korelasi Spearman didapatkan sebesar 0,537 menunjukkan bahwa arah korelasi positif dengan kekuatan korelasi sedang.

Hasil studi ini sejalan dengan penelitian yang dilakukan oleh Puspasari di RSUD Undata Kota Palu, yaitu hubungan yang signifikan antara jumlah leukosit pre operasi dengan komplikasi pasca operasi apendisitis perforasi. ${ }^{22}$ Penelitian ini juga sesuai dengan yang dilakukan oleh Kogut et al pada tahun 2001 di USA yang menunjukkan adanya keterkaitan antara peningkatan leukosit dengan kegagalan dan komplikasi yang meningkat. $^{26}$

Komplikasi pada apendisitis perforasi dihubungkan dengan tingginya leukosit darah saat diagnosa ditegakkan, lamanya penanganan sejak gejala muncul dan gejala demam tinggi lebih dari 38,5 ${ }^{0} \mathrm{C}$ sebagai bentuk respon inflamasi tubuh. Peningkatan jumlah leukosit menandakan adanya suatu proses inflamasi akut yang merupakan reaksi awal dari jaringan lokal dan pembuluh darah terhadap suatu jejas. Hal tersebut bisa menjadi salah satu prediksi dalam terjadinya komplikasi pada apendisitis perforasi. $^{17,27}$

Penelitian ini terfokus kepada jumlah leukosit pre operasi terhadap komplikasi pasca operasi yang dilakukan. Hal-hal seperti pengontrolan pasca operasi, perbedaan operator yang melakukan operasi dan antibiotik yang digunakan, jumlah pus yang ada, teknik operasi apendektomi yang digunakan, kegiatan setelah 
operasi seperti penjahitan, drainase serta tension yang dapat menyebabkan infeksi secara tidak langsung tidak bisa ditampilkan pada penelitian ini dikarenakan tidak adanya informasi tersebut pada rekam medis yang menjadi keterbatasan penelitian.

Keterbatasan penelitian ini seperti yang disebutkan diatas adalah karena merupakan penelitian retrospektif sehingga tidak dapat mengumpulkan beberapa data penting yang mungkin mempengaruhi hasil, seperti penggunaan antibiotik. Perbedaan antara jumlah leukosit yang didapatkan lebih rendah kemungkinan karena beberapa pasien telah mengkonsumsi antibiotik sebelum diperiksa jumlah leukositnya. Pemberian antibiotik juga mempunyai peranan dalam menurunkan mortalitas dan morbiditas pada pasien walaupun pembedahan merupakan gold standart dari apendisitis perforasi selama tidak terjadi resistensi dan sesuai dengan pola kuman penyebab dari apendisitis tersebut.

\section{SIMPULAN}

Terdapat hubungan antara jumlah leukosit pre operasi dengan kejadian komplikasi pasca operasi apendektomi pada pasien apendisitis perforasi di RSUP Dr. M. Djamil Padang dengan derajat kekuatan hubungan sedang.

\section{DAFTAR PUSTAKA}

1. Dorland WAN. Kamus kedokteran Dorland. Edisi ke31. Albertus Agung Mahode, editor (penyunting). Jakarta: EGC; 2010.hlm.137-8.

2. McCance KL, Huether SE. Pathophysiology: The biologic basis for disease in adults and children. Edisi ke-5. Philadelphia: Elsevier; 2006.

3. Berhman RE, Kliegman RM, Jenson HB. Nelson's text book of pediatric. Edisi ke-17. Philadelphia: Saunders; 2003.

4. Mazziotti MV, Minkes RK. Appendicitis: surgical perspective. E-Medicine 2006. (diunduh 8 September 2017). Tersedia dari: http://www. emedicine.com/ped/topic2925.html

5. World Health Organization (WHO). Global burden disease. WHO 2004. (diunduh 8 September 2017). Tersedia dari: http://www.who.int/healthinfo/global burden diseas e/BD report 2004update AnnexA.pdf

6. Zinner MJ, Ashley SW. Maingot's abdominal operation. Edisi ke-11. New York: McGraw-Hill; 2007.

7. Departemen Kesehatan RI. Profil kesehatan Indonesia 2009 (diunduh 5 September 2017). Tersedia dari: http://www.depkes.go.id/downloads/ profil Kesehatan 2009/index.html

8. Humes DJ, Simpson J. Clinical review: acute appendicitis. 2006 (diunduh 8 September 2017). Tersedia dari: http://www.bmj.com/cgi/content/ full/333/7567/530.

9. Al-Omran M, Mamdani MM, Mc Leod R. Epidemiologic features of acute appendicitis in Ontario, Canada. Can J Surg. 2003 Aug; 46(4): 263-8.

10. Rekam medik RSUP Dr. M. Djamil Padang. Jumlah Kejadian Apendisitis Perforasi. RSUP Dr. M.Djamil Padang; 2017.

11. Soybel DI, Norton JA, Bollinger RR, Chang AE, Lowry SF, Mulvihill SJ, et al. Appedix In surgery basic science and clinical evidence vol 1. New York: Springer Verlag Inc; 2000.hlm. 647-62.

12. Schwartz SI, Shires GT, Spencer FC, Daly JM, Fischer JE, Galloway AC. Principles of surgery. United States of America: McGraw-Hill companies; 2005.

13. Kasper DL. Harrison's principle of internal medicine. Edisi ke-16. New York: McGraw-Hill; 2005.

14. Seetahal, Bolorunduro OB, Sookdeo TC, Oyetunji TA, Greene WR, Frederick W, et al. Negative appendectomy: a 10 year review of nationally representative sample. American Journal Surgery. Am J Surg. 2011 Apr;201(4):433-7.

15. Sjamsuhidayat $R$, Wim DJ. Buku ajar ilmu bedah. Edisi ke-2. Jakarta: EGC; 2004.

16. Ortega $P$. Usefulness of laboratory data in the management of right iliac fossa pain in adult. Madrid, Spain. Department of General and Digestive Surgery Hospital Universitario de Getafe. 2008;51: 1093-9.

17. Ahuja V. Wound healing. Dalam: Brunicardi FC, Andersen DK, Billiar TR, Dunn DL, editor (penyunting). Schwartz's Principles of Surgery. Edisi ke-9. Philadelphia: The Mc Graw-Hill Companies; 2010.hlm.159-67. 
18. Asrahadi T. Hubungan pola kuman dan faktor host terhadap resiko kejadian apendisitis perforasi (tesis). Padang: Fakultas Kedokteran Universitas Andalas; 2017.

19. Marissa, Junaedi HI, Setiawan MR. Batas angka leukosit antara apendisitis akut dan apendisitis perforasi di rumah sakit umum daerah Tugurejo Semarang Januari 2009-Juli 2011 (skripsi). Semarang: Fakultas Kedokteran Universitas Muhammadiyah Semarang; 2012.

20. Sengupta A, Bax G, Peterson-Brown S. White cell count and $c$-reactive protein measurement in patient with possible appendicitis. Ann R Coll Surg Engl. 2009 Mar; 91(2):113-5.

21. Gearhart, Susan L, Wiliam S. Acute appendicitis and peritonitis. USA: McGraw-Hill. 2008. hlm. 1914-6.

22. Puspasari V, Hubungan kadar leukosit pre operasi dengan kejadian komplikasi perforasi pada pada pasien apendisitis akut yang dioperasi di RSUD Undata (skripsi). Palu: Fakultas Kedokteran Universitas Negeri Palu; 2012.
23. Sirikurnpiboon S, Amornpornchareon S. Factors associated with perforated appendicitis in elderly patients in a tertiary care hospital. Department of Surgery, Rajavithi Hospital, College of Medicine, Rangsit University, Phayathai Road, Rajathewee, Bangkok 10400, Thailand; 2015.

24. Omari, AH, Khammash MR, Qasaimeh GR, Shammari AK, Yaseen MKB, Hammori SK. Acute appendicitis in the elderly: risk factors for perforation. World Journal of Emergency Surgery. 2014;9:6 hlm.

25. McPhee SJ, Papadakis MA, Tierney LM. Current Medical Diagnosis and Treatment. Edisi ke-47. San Francisco: McGraw-Hill; 2008.

26. Kogut KA, Blakely ML, Schropp KP, Deselle W, Hixson SD. The association of elevated percent bands on admission with failure and complications of interval appen-dectomy. J Pediatr Surg. 2001; Jan;36(1):165-8.

27. Price SA, Wilson LM, 2006, Patofisiologi: konsep klinis proses-proses penyakit. Edisi ke-6. Anugrah P, penterjemah,. Jakarta: EGC; 2006. 